\section{Science of Food.}

(1) Bacteriology and Mycology of Foods. By Dr. Fred Wilbur Tanner. Pp. vi $+592+$ to plates. (New York: John Wiley and Sons, Inc.; London: Chapman and Hall, Ltd., I919.) Price $28 s$. net.

(2) Food: Its Composition and Preparation. A Text-book for Classes in Household Science. By Mary T. Dowd and Jean D. Jameson. (The Wiley Technical Series.) Pp. viii + i73. (New York: John Wiley and Sons, Inc.; London: Chapman and Hall, Ltd., I918.) Price $6 s$, net.

THESE two books are very laudable attempts $I$ by our American cousins to place the important question of food on a scientific basis. The war brought home to people at large the importance of such study, but one hopes, in days of peace, not only that investigations will continue, but also that their application will be carried out to a greater extent.

(I) The first of the two books mentioned above is very complete, not only in the number of important foods dealt with, but also in the numerous methods of investigation described to detect impurities and prevent contamination with undesirable admixtures. It is the science of cleanliness in technical costume. The preface informs us that the work is written for those who wish to fit themselves for food control; but as it presupposes a thorough training in bacteriology and chemistry, we fear it will scarcely appeal to those who are food controllers here. What is really wanted is a book that he who runs may read, a book intelligible to the manufacturer, the packer, the tradesman, and the housewife. To present such with the graphic formulæ of, say, amino-acids and fats would be simply to terrify them. Still, the book should be useful to a more limited section of the population -namely, the analysts and bacteriologists. Its price strikes one as exorbitant even in these days of high charges.

(2) The second book is of a much more practical nature, and will be welcomed by all those engaged in the study of household science. It is an excellent chemical introduction to the science of intelligent cookery. The authors have taken care to provide themselves with a good preliminary knowledge of physiology and bio-chemistry, and if they go a little wrong in a few details, such as in their account of the vitamines, the slips are trivial, and do not affect their main arguments or their main endeavour, which is to rescue cookery from the domain of empiricism and ignorance.

W. D. H.

\section{Our Bookshelf.}

Petrology for Students: An Introduction to the Study of Rocks under the Microscope. By Dr. Alfred Harker. Fifth edition, revised. (Cambridge Geological Series.) Pp. viii +300 . (Cambridge: At the University Press, 1919) Price $8 s .6 d$. net.

A HEARTY welcome must be extended to this new edition of one of our most widely known greological text-books, which has had considerable influence in securing systematic and accurate descriptions of rocks by British petrologists. The present edition contains a few pages less than the previous issue, but this has been accomplished by diminishing the space at the headings of chapters and by the excision of superfluous notes and references to occurrences of minor interest, so that the value of the book is in no way diminished. New illustrations have been added, and the chapters on metamorphism largely re-written.

As in previous editions, the author rejects names given unnecessarily to local varieties, which he distinguishes simply by reference to the places from which the names were formed. This process might with advantage have been carried very much further. There is, however, already so much diversity in petrological nomenclature, not only in different countries, but also among individual geologists, that the author is probably wise in refraining from attempting any farreaching reforms.

Perhaps in another edition a certain number of analyses of the more important rock-species might be included, as well as their specific gravities,. which afford a valuable means of checking the determination of rocks in the field. J. W. E.

Chemistry and its Mysteries: The Story of What Things are Made Of, Told in Simple Language. By Charles R. Gibson. (Science for Children.) Pp. 246. (London: Seeley, Service, and Co., Ltd., I920.) Price 4s. 6d. net.

HERE is another of Mr. Gibson's wonderful books for children. This time Mr. Gibson treats of the elements of chemistry, the conception of chemical constitution, combustion and respiration, electrolysis, spectroscopy, and "queer things" such as radium and liquid air. The author has not lost his powers of stating scientific propositions in simple and attractive form without departing (except in quite minor details) from the strictest accuracy. We confess that we had thought modern children rather more sophisticated and apt to regard as ridiculous analogies drawn from nursery games; but in this matter we bow to Mr. Gibson's judgment. His success in what he has set himself to do is beyond question; criticism, if any were offered, would concern rather his objects. But this is not the place to inquire whether it is really useful, or even harmless, to present the complex and highly theoretical conclusions of modern science without any serious. attempt to present also the evidence on which they are based. 